\title{
ANTIOXIDANT POTENTIAL AND QUALITY CHARACTERISTICS OF GRAPE PEEL-ENRICHED RICE-BASED EXTRUDED FLOUR AS POTENTIAL NOVEL FOOD
}

Data de aceite: $21 / 09 / 2020$

\section{Isabela Pereira Reis}

Federal Rural University of Rio de Janeiro UFRRJ

Seropédica - RJ http://lattes.cnpq.br/5327012702134432

José Luis Ramírez Ascheri

Embrapa Food Agroindustry

Guaratiba - RJ

http://lattes.cnpq.br/5327012702134432

\section{DOI 10.22533/at.ed.33720280914}

ABSTRACT: Grape peel (GP) and rice flour (RF) blends were processed by extrusion in order to add value to the by-products of the grape juice and winery industry. The (GP) inclusion levels of $(10,15$ and $20 \%)$ temperature $(120,130$ and $\left.140^{\circ} \mathrm{C}\right)$, and feed moisture (15, 17 and $19 \%$ ) on the physicochemical and properties of extruded RF and GP flour where investigated. Screw speed extruder was constant at $150 \mathrm{rpm}$; barrel temperatures in the first and the second zones were constant at 50 and $90^{\circ} \mathrm{C}$, respectively. The addition GP at a level of $15 \%$, combined with the higher moisture content (20.4\%) significantly decreased the water absorption index (WAI), and the water solubility index (WSI) increased with the lowest level of moisture (13.6\%). The total phenolic did not reduce content significantly, compared to the raw GP flour sample. The results indicated the presence of active interactions between the grape rind and the rice starch during the expansion process that is not present as an inert material. The precooked RF and GP can be indicated for food formulation/development, with emphasis on natural antioxidants and fibre.

KEYWORDS: Grape peel, rice flour, extrusion, expansion, absorption, by-products.

POTENCIAL ANTIOXIDANTE E CRACTERÍSTICAS DE QUALIDADE DE FARINHA DE ARROZ E CASCA DE UVA EXTRUDADO COMO NOVO PRODUTO ALIMENTÍCIO

RESUMO: As misturas de casca de uva (FCU) e farinha de arroz (FA) foram processadas por extrusão, a fim de agregar valor aos subprodutos da indústria de suco de uva e vinícola. Os níveis de inclusão (FCU) de temperatura (10, 15 e 20\%) $\left(120,130\right.$ e $\left.140^{\circ} \mathrm{C}\right)$ e umidade de alimentação (15, 17 e 19\%) nas propriedades físico-químicas e nas propriedades da farinha extrusada de FA e FCU foram investigados. A velocidade do parafuso da extrusora foi constante a 150 rpm; as temperaturas do barril na primeira e na segunda zonas eram constantes a 50 e $90^{\circ}$ $\mathrm{C}$, respectivamente. A FCU de adição em um nível de $15 \%$, combinado com o maior teor de umidade $(20,4 \%)$ diminuiu significativamente 0 índice de absorção de água (WAI), e o índice de solubilidade em água (WSI) aumentou com o menor nível de umidade $(13,6 \%)$. O composto fenólico total não reduziu significativamente comparado com a amostra de farinha de casca de uva crua. Os resultados indicaram a presença de interações ativas entre a casca da uva e o amido de arroz durante o processo de expansão que não está presente como material inerte. A FA e FCU pré-cozidos podem ser indicados para 
formulação/desenvolvimento de alimentos, com ênfase em antioxidantes e fibras naturais.

PALAVRAS-CHAVE: Casca de uva, farinha de arroz, extrusão, expansão, solubilidade, absorção, subprodutos.

\section{1 | INTRODUCTION}

Collection of food processing industries are sources of compounds of considerable value, such as dietary fibres, antioxidants, essential fatty acids, antimicrobials, and minerals, which can be used in the elaboration and development of new products, due to their properties, nutritional and technological. It is estimated that 73 million tons of grapes, mainly cultivated as Vitis vinifera, are produced worldwide of which grape pomace represents approximately $20 \%$ of the total volume (ROCKENBACH et al., 2011).

Not surprisingly, there is an increased demand for the conversion of agro-industrial waste into products of high nutritional and functional value, for example, the use of grape marc. Besides the possibility of developing new ingredients or finished products with a transformation of these, and to be obtained with low cost and in large quantity, another factor that justifies its use is a reduction of the environmental impact caused by its generation and deposition (FERREIRA, 2012). The main agroindustry residues of winemaking are separated during the crushing and pressing stages of the grapes, of which only small quantities of these grapes are valued or used (MONRAD et al., 2010).

The grape peel is characterized by a phenolic content, due to the low quality availability during winemaking, since, even after contact with a wine fermentation, the grape marc continues to contain phenolic compounds with a potential antioxidant capacity (GONZÁLEZNEVES et al., 2015).

Rice (Oryza sativa L.), a crop that adapts to different soil and climate conditions, is a cereal grown and consumed worldwide. Approximately $90 \%$ of all the world's rice is grown and consumed in Asia (FAOSTAT, 2016). In the impossibility of consuming wheat, usually uses a rice flour for being one of the best options for elaborating foods products for celiac. In addition to being non-allergenic, rice flour and a versatile product have mild taste, low sodium levels and high proportion of readily digestible starch (PRASAD et al., 2012). Rice consists mainly of starch, presenting smaller amounts of proteins, lipids, fibres and ashes. As outer layers, higher concentrations of proteins, lipids, fibre, minerals and vitamins, while the centre is rich in starch.

Developing foods and suitable technologies for fibre and antioxidants addition in food is often a challenge. The presence of fibre in rice-based extruded products may shorten the intestinal transit time of the product, increase the rate of intestinal absorption of glucose, decrease blood cholesterol levels and reduce the content of calories ingested (ASCHERI, 2014). It is believed that grape marc (by-product of viticulture) can provide in addition to dietary fibre, mineral salts and proteins remaining from the biological agent used for the 
fermentation of grape juice.

Fortunately, extrusion provides one alternative technology. Extrusion commonly used to produce breakfast cereals and snacks (BRENNAN et al., 2011) generally composed of cereal grains with significant amounts of starch (BRNCIC et al., 2011; PEKSA et al., 2016; PATHAK and KOCHHAR, 2018). The extrusion process causes hydration of starch and proteins, homogenization, starch gelatinization, fat liquefaction, partial protein denaturation and expansion of the processed material, among others (TOLEDO et al., 2019). The starch, being pregelatinised, undergoes chemical transformations that cause swelling and rupture of the granules, causing modifications of the crystalline structures that consequently increase the solubility and the viscosity in cold water (SHI et al., 2011), increasing the potential in the production of instant foods. Variations in the extrusion operating conditions can be used which allow the production of extrudates with various characteristics, such as providing high level of water absorption, indicated in the preparation of porridges and soups, or high degrees of solubility allowing their use in beverages (SWAPNIL et al., 2016).

In view of the above, the object of this work was to evaluate the effect of GP inclusion levels, the moisture content and extrusion conditions on the expansion, water absorption and solubility indexes during extrusion processing and valorisation of antioxidants of extruded rice and grape peel flour as potential novel food.

\section{I MATERIALS AND METHODS}

\subsection{Raw Materials}

\subsubsection{Preparation of extruded flour from rice flour and grape peel}

The grape bagasse was supplied by Embrapa Semi arid (Petrolina, PE, Brazil), from the Alicante Bouschet variety, from the 2016/2017 harvest, from the production of red wine, provided by the Santa Maria winery of the ViniBrasil group (Lagoa Grande, PE, Brazil). The sample was collected after fermentation of the grapes ( 2 or 3 weeks). The bagasse in natura (bark and seed) was previously dried in an oven at $45^{\circ} \mathrm{C}$ for 168 hours ( 7 days) at Embrapa Semi arid. The bagasse in natura (bark and seed) was previously dried, and the conditions of the drying process were established from results obtained in preliminary tests. After cooling, the bagasse was sent to Embrapa Food Agroindustry (Rio de Janeiro, RJ, Brazil), and the separation procedure was started. The separation of the bark and seeds was carried out with the aid of sieves. Firstly, the dried bagasse was passed through a $3 \mathrm{~mm}$ sieve in order to reduce the particle size and, afterwards, a $2 \mathrm{~mm}$ sieve was used in order to separate the seed husk and the seed was retained in the sieve. Both methods were performed by manual friction.

The peels were then the ground in a zero-aperture disk mill (Perten Laboratory Mill 
3600, USA) to obtain the grape-flesh flour, which was sieved in a Ro-tap vibrating classifier with a set of $5,9,12,16,24$ mesh and a base for 10 minutes and at maximum speed for standardizing the particle size in a set of 16 to 24 mesh screens, for use in extrusion.

The rice was supplied as grains (type 2), obtained by local commerce, analysed microbiologically, and physically, milled in disco mill, obtaining rice flour.

Grape peel and rice flours were then stocked at room temperature and under light, and then vacuum packed.

\subsection{Extrusion Processing Conditions and Experimental Design}

A single screw extruder brand Brabender, model DSE20 DN (Duisburg, Germany), with compression ratio of 3:1 was used. The screw rotation was constant at $150 \mathrm{rpm}$. The aperture of the circular die was $3 \mathrm{~mm}$ in diameter, constant temperatures in the first and second heating zones of the extruder of $50^{\circ} \mathrm{C}$ and $90^{\circ} \mathrm{C}$, respectively. The temperature in the third zone varied as described in the experimental design. Totally 19 runs using the mix flour (rice flour/ Grape peel flour) using 10, 15 and 20\% of grape peel flour and the difference with rice flour, beyond the axial points (6.6 and $23.4 \%$ of grape peel flour).

Before the extrusion process itself, mixed flours according to the established proportions (rice/grape peel) were subjected to a moisture conditioning process, as described in the experimental design.

In order to better correlate extrusion parameters in the preparation of pre-cooked mixed rice and grape rind flour, a rotational central composite (DCCR) type design was used, considering three variables (percentage of grape/rice flour in the mixture, temperature $\left({ }^{\circ} \mathrm{C}\right.$ ) and processing moisture (\%) for the preparation of a pre-cooked mixed flour.

Data processing and statistical analysis were performed using the statistical software Statistica, version 7.0 (STATSOFT INC. 2004), with the coded independent variables. The levels of each independent variable were set according to the preliminary tests and data related to the literature. The coded value $( \pm 1$ and 0$)$ and the value of the independent variables with a project matrix are given in the tables with the results. A second-order polynomial model was employed for the three-factor design, which is given a

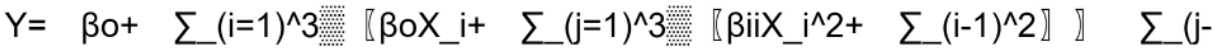

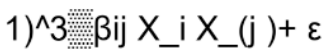

where $\mathrm{Y}$ is the expected response, $\beta 0$ the constant coefficient, $\beta i$ the linear coefficient, represent, $\beta \mathrm{ii}$ the quadratic coefficients, $\beta \mathrm{ij}$ the interaction coefficients and $\mathrm{Xi}, \mathrm{Xj}$ the coded values of the process variables and $\varepsilon$ the residual error (Diamante et al. 2012). In the current study $\beta 1, \beta 2$ and $\beta 3$ are the coefficients of flour level of grape rind, temperature in the third zone of the extruder and moisture content, respectively. 


\subsection{Process Responses}

\subsubsection{Specific Mechanical Energy}

Specific Mechanical Energy (SME) is the mechanical energy input per unit mass of extrudates. The results were expressed as kilojoules per kilogram. Torque was recorded by the data acquisition system for Intelli-Torque (CW Brabender, S. Hackensack, NJ, USA) every 30-s interval during steady-state operating conditions.

\subsubsection{Radial Expansion Index}

The radial expansion (REI), was determined by calculating the mean diameter of 15 randomly chosen locations on the extrudates with calipers for a single process condition and then dividing by the final die diameter of $3 \mathrm{~mm}$.

Bulk Density.

Bulk density (BD) was determinate by displacement of 1.0-mm-diameter glass beads (General Laboratory Supply, Pasadena, TX, USA). The results were expressed as kilograms per cubic meter (Alvarez-Martinez et al. (1988).

Water Solubility Index and Water Absorption Index.

The determination of the water solubility (WSI) and water absorption (WAI) indexes of the samples was performed according to the basic principles of the method described by Anderson et al. (1969).

\subsubsection{Pasting properties}

The pasting properties where performed according to the methodology recommended by the American Association of Cereal Chemists (AACC 2010). Extruded samples of GP and RF were determined in Rapid Visco Analyser (RVA), (RVA4, Newport Scientific, Warriewood, NSW, Australia), with analysis profile "extrusion 1 no-alcohol". This analysis was performed in duplicate and a ground sample suspension ( $3 \mathrm{~g}$ in $25 \mathrm{~mL}$ ) corrected to $14 \%$ moisture was used such that the final mass was $28 \pm 0.01 \mathrm{~g}$. Initially the system was maintained at $25^{\circ} \mathrm{C}$ for 2 minutes, and heating then reached $95^{\circ} \mathrm{C}$ at 7 minutes, where it remained for 3 minutes. Soon after, the cooling was started until the temperature of $25^{\circ} \mathrm{C}$ again, totalling 20 minutes of analysis. The viscosity peaks $(\mathrm{V})$ in $\mathrm{cP}$ and the corresponding time (t) in min were recorded by a computer using the Thermocline software (Newport Scientific, Warriewood, NSW, Australia). Samples were kept $2 \mathrm{~min}$ at $25^{\circ} \mathrm{C}$, heated to $95^{\circ} \mathrm{C}$, held at $95^{\circ} \mathrm{C}$ for $3 \mathrm{~min}$ and cooled to $25^{\circ} \mathrm{C}$, under stirring at $160 \mathrm{rpm}$. The parameters of initial viscosity (or cold viscosity), maximum viscosity, breakdown, tendency to retrograde (setback) and final viscosity in the cooling cycle were analysed. 


\subsubsection{Mechanical properties}

The samples used in the determination of the expansion indices were dried in an air-circulating oven (WTB Binder, Tuttlinger, Germany) at $60^{\circ} \mathrm{C}$ until a remaining moisture of less than $4 \%$ (approximately $4 \mathrm{~h}$ ) was reached. Then the snacks were cooled in a desiccator to room temperature. The mechanical properties of the extrudates were measured using the puncture test with a TA-XT Plus texture analyser (Stable Micro Systems, Surrey, England) equipped with a $50 \mathrm{~kg}$ load in which was coupled a cylindrical stainless steel probe of $2 \mathrm{~mm}$ in diameter. The probe dropped to $5 \mathrm{~mm} . \mathrm{s}-1$, when it reached a contact force of $0.196 \mathrm{~N}$ under the sample, then the drilling started at $1 \mathrm{~mm} . \mathrm{s}-1$ up to $50 \%$ of the extrudates (D/2) diameter. The probe rose to $10 \mathrm{~mm} . \mathrm{s}-1$, up to a height of $20 \mathrm{~mm}$. A total of 15 perforations were made for each type of extrudates. The peaks of compression forces $(F)$ in $N$, and the corresponding time $(\mathrm{t}$ ) in min were recorded by Exponent software version 4.0.13.0 (Stable Micro Systems, Surrey, England).

\subsection{Physicochemical characterization of extruded flours}

\subsubsection{Centesimal composition}

Moisture, protein, lipids and ash analyses were based on the methods described by AOAC (2010). Total carbohydrates were obtained by the method described by USP (2008). The total dietary fibre content was determined according to the enzymatic-gravimetric method (AOAC 2010).

\subsubsection{Determination of color}

The instrumental color of the extruded blends and grape peel flour was measured using the Konica Minolta CR 400 colorimeter. Using the $L^{*}, a^{*}, b^{*}$ CIE (Commission Internationale de L'Eclairage) system, in which $L^{*}$ determines the brightness, that is, how bright or dark the sample is, $a$ *, the chromatic intensity of green to red, and $b$ * which expresses the intensity of blue to yellow (Patel et al. 2016).

\subsection{Determination of the antioxidant capacity of grape peel flour and extruded blend products}

The lack of standardization of these methods makes it difficult to compare data published by different research groups, mainly by the use of different solvents and the different ways of expressing the results. In addition, variations in the antioxidant complex of a food matrix may provide different responses in each method. Therefore, it is recommended the combination of at least two of these methods to provide more complete and representative results of the antioxidant capacity of fruits (Pérez-Jiménez et al. 2008).

Preparation of extracts

For the determination of the antioxidant capacity, an extract was used for the analysis 
by ABTS (2,2'-azino-bis (3-ethylbenzothiazoline) 6-sulphonic acid), a method adapted from Jeng et al. (2012) and by ORAC (Oxygen Radical Absorbance Capacity), a method adapted from Thaipong et al (2006).

\section{Method \\ 2.5.1 ABTS (2,2'-azino-bis (3-ethylbenzothiazoline) 6-sulphonic acid)}

The antioxidant capacity equivalent to Trolox was estimated according to a procedure proposed by Jeng et al. (2012) with some modifications. The ABTS - + radical was prepared from the reaction of $7 \mathrm{mM}$ aqueous ABTS solution with $140 \mathrm{mM}$ potassium persulfate, leaving the mixture at room temperature for 16 hours in the absence of light. Then, the ABTS solution was diluted with ethanol to obtain an absorbance of 0,70 $\pm 0,05$ at $734 \mathrm{~nm}$. Aliquots of $30 \mu \mathrm{L}$ of the samples were added to $3 \mathrm{~mL}$ of the diluted ABTS solution, and the absorbance were recorded at the end of six minutes. The antioxidant capacity was calculated using standard Trolox curve (100 to $2000 \mu \mathrm{M}$ ) and their respective inhibition percentages, and the test results were expressed in $\mu \mathrm{mol}$ of Trolox equivalent per gram fresh weight ( $\mu \mathrm{mol}$ TE.g-1 PF ).

\subsubsection{Oxygen Radical Absorbance Capacity (ORAC) Method}

The absorption capacity of oxygen radicals was analysed as proposed by Thaipong et al (2006). In microplates, $25 \mu \mathrm{L}$ aliquots of the extracts were mixed with $150 \mu \mathrm{L}$ of the fluorescein solution ( $40 \mathrm{nM}$ ) and incubated at $37^{\circ} \mathrm{C}$ for 30 minutes to the addition of $25 \mu \mathrm{L}$ of the AAPH solution (153 nM). All reagents were prepared in phosphate buffer $(75 \mathrm{mM}, \mathrm{pH} 7,1)$. Fluorescence intensity (excitation at $485 \mathrm{~nm}$ and emission at $525 \mathrm{~nm}$ ) was monitored every 60 minutes on the Sinergy Mx microplate reader (BioTeK, Winooski, USA). The standard curve was prepared with Trolox solution (6.25 to $100 \mathrm{mM}$ ), and the results were expressed in $\mu \mathrm{mol}$ equivalent of Trolox per gram fresh weight ( $\mu$ mol Trolox.g-1 PF).

\subsubsection{Determination of total phenolic compounds}

The quantification of the total phenolic of extracts and products was performed as recommended by Georgé et al. (2005). The reading was carried out at $720 \mathrm{~nm}$ after reduction of the reagent by the phenolic compounds. The results were expressed in mg of catechin per $100 \mathrm{~g}$ of grape peel flour and in the extruded product in order to evaluate the effect of the extrusion on the total phenolic compounds content.

\subsubsection{Determination of total anthocyanins}

The methodology used in the determination of total anthocyanins from the extracts was of $\mathrm{pH}$ difference, according to Lee et al. (2005). The determination was carried out in the grape peel flour sample and in the extruded flours in order to evaluate the effect of the extrusion on the total anthocyanins content. 


\section{I RESULTS AND DISCUSSION}

\subsection{Physicochemical characterization of extruded flours}

\subsubsection{Centesimal composition}

The results of the centesimal composition for the extruded mixed rice and grape rind are presented in Table 1.

\begin{tabular}{|c|c|c|c|c|c|c|c|c|c|}
\hline Treatment & $\begin{array}{c}\text { Grape }^{*} \\
\text { peel } \\
\text { proportion } \\
(\%)\end{array}$ & $\begin{array}{c}\text { Temperature } \\
\left({ }^{\circ} \mathrm{C}\right)\end{array}$ & $\begin{array}{c}\text { Moisture } \\
\text { Content } \\
(\%)\end{array}$ & $\begin{array}{l}\text { Moisture } \\
\text { content } \\
\text { after } \\
\text { extrusion }\end{array}$ & Ash & Protein & Lipid & Carbohydrate & Fibre \\
\hline 1 & 10 & 120 & 15 & 6.78 & 1.14 & 1.21 & 1.98 & 88.89 & N.D \\
\hline 2 & 10 & 120 & 19 & 6.14 & 1.21 & 1.23 & 1.82 & 89.60 & N.D \\
\hline 3 & 10 & 140 & 15 & 6.56 & 1.26 & 1.22 & 1.92 & 89.04 & N.D \\
\hline 4 & 10 & 140 & 19 & 5.41 & 1.20 & 1.25 & 2.14 & 90.00 & N.D \\
\hline 5 & 20 & 120 & 15 & 5.95 & 1.90 & 1.30 & 2.50 & 88.35 & N.D \\
\hline 6 & 20 & 120 & 19 & 6.24 & 1.86 & 1.34 & 2.59 & 87.97 & N.D \\
\hline 7 & 20 & 140 & 15 & 6.70 & 1.83 & 1.27 & 1.52 & 88.68 & N.D \\
\hline 8 & 20 & 140 & 19 & 6.12 & 1.77 & 1.33 & 1.90 & 88.88 & N.D \\
\hline 9 & 6.6 & 130 & 17 & 6.80 & 0.94 & 1.22 & 1.43 & 89.61 & N.D \\
\hline 10 & 23.4 & 130 & 17 & 6.57 & 2.00 & 1.31 & 2.55 & 87.57 & N.D \\
\hline 11 & 15 & 113.2 & 17 & 6.10 & 1.37 & 1.26 & 1.96 & 89.31 & N.D \\
\hline 12 & 15 & 146.8 & 17 & 6.25 & 1.39 & 1.28 & 1.99 & 89.09 & N.D \\
\hline 13 & 15 & 130 & 13.6 & 6.86 & 1.33 & 1.27 & 1.75 & 88.79 & 20.45 \\
\hline 14 & 15 & 130 & 20.4 & 6.38 & 1.40 & 1.28 & 1.66 & 89.28 & 20.32 \\
\hline 15 & 15 & 130 & 17 & 7.01 & 1.65 & 1.28 & 1.74 & 88.32 & 19.46 \\
\hline 16 & 15 & 130 & 17 & 6.32 & 1.69 & 1.25 & 1.98 & 88.76 & N.D \\
\hline 17 & 15 & 130 & 17 & 5.87 & 1.60 & 1.27 & 1.99 & 89.27 & N.D \\
\hline 18 & 15 & 130 & 17 & 6.39 & 1.71 & 1.28 & 2.13 & 88.49 & N.D \\
\hline 19 & 15 & 130 & 17 & 6.54 & 1.62 & 1.27 & 1.86 & 88.71 & N.D \\
\hline
\end{tabular}

Table 1. Chemical composition of extruded mixed rice and grape peel according with experimental design. Results of centesimal composition expressed in $\mathrm{g} .100 \mathrm{~g}^{-1}$; ND = not determined. * The other percentage corresponds to rice flour.

The moisture content of the extruded flours was between 5.41 and $7.01 \mathrm{~g} .100 \mathrm{~g}-1$ of dry sample, reflecting the ideal for a rice flour, which should have a maximum of $13 \mathrm{~g} .10 \mathrm{~g}-1$ of moisture (AACC, 2010). The protein content varied from 1.21 to $1.34 \mathrm{~g} .100 \mathrm{~g}$-1 of dry sample, values found below those reported by Llobera and Cañellas (2007) and Sáyago-Ayerdi et al. 
(2009). The protein content of the grape depends on the cultivar and its proteins are present mainly in the grape pulp. In vinification and in the pressure stage, depending on the intensity, may lead to a decrease in the content of soluble proteins in the bagasse. At the end of the fermentation process, many proteins precipitate with the tannins, mainly in the elaboration of the red wine (Jackson 2008). Differences in the chemical composition of agroindustry residues from winemaking, such as GP, are attributed to agro climatic factors and oenological practices of the vineyard region, such as vineyard management, irrigation, fertilization and sanitary status of grapes of the harvest. The low lipid content observed (2.59\%) is due to the use of the peel alone to obtain the flour, with the highest lipid content being found in the seeds, between $10 \%$ and $16 \%$ depending on the variety (LUQUE-RODRIGUEZ et al., 2005). The lipid content ranged from 1.43 to $2.59 \mathrm{~g}$. $100 \mathrm{~g}-1$. This component is mainly associated with the seeds and, as the flour is from the GP and there may be some seed remnants, presented a value closer to the fraction of the peel. The lipid content of the GP fraction of this study is included among the values found by Romero et al. (2016), which was $1.07 \mathrm{~g} .100 \mathrm{~g}-1$.

Carbohydrates are the components that are found in higher percentage in the precooked mixed RF and GP. Although the protein and lipid content is close to 2.5 and $1.5 \%$, respectively, this flour cannot be considered as a source of protein, but as a source of energy.

The regression variables (Table 2) for the centesimal composition indicated that the second-order polynomial model did not have a good correlation for the responses $(\mathrm{R} 2=$ $0.6412)$ and lipids $(R 2=0.7091)$, not being valid for predictive purposes $(p<0.05)$. The results of the regression analysis revealed that the temperature in the third zone of the extruder (x2) and the moisture $(\mathrm{x} 3)$ had a significant quadratic effect under the ash content in the flours, related to the proportion of 1 .

\begin{tabular}{|c|c|c|c|c|c|c|c|c|c|c|c|}
\hline \multirow{2}{*}{ Answer } & \multicolumn{10}{|c|}{ Model } & \multirow{2}{*}{$\mathrm{R}^{2}$} \\
\hline & $\beta_{0}$ & $\beta_{1}$ & $\beta_{2}$ & $\beta_{3}$ & $\beta_{11}$ & $\beta_{22}$ & $\beta_{33}$ & $\beta_{12}$ & $\beta_{13}$ & $\beta_{23}$ & \\
\hline $\begin{array}{l}\text { Moisture after } \\
\text { extrusion }\end{array}$ & 6.436 & & & -0.211 & & & & & & & 0.6412 \\
\hline Ash & 1.614 & 0.317 & & & & -0.063 & -0.069 & & & & 0.9361 \\
\hline Protein & 1.269 & 0.035 & & 0.012 & & & & & & & 0.8448 \\
\hline Lipid & 1.934 & 0.186 & & & & & & -0.241 & & & 0.7091 \\
\hline Carbohydrate & 88.711 & -0.518 & & & & & & & & & 0.8576 \\
\hline WAI & 13.758 & & 4.409 & & & & 5.540 & & & & 0.5848 \\
\hline WSI & 11.704 & & & -1.967 & & & & & & & 0.8417 \\
\hline BD & 229.747 & 15.603 & & 86.845 & & & & & & & 0.9001 \\
\hline REI & 5.310 & -0.604 & & -1.348 & & & 0.178 & & & & 0.9737 \\
\hline CMV & 466.570 & & & & & & & & & & 0.4769 \\
\hline Breakdown & 356.451 & & & & & & & & & & 0.3914 \\
\hline Setback & 240.300 & -77.475 & & 47.9276 & & & & & & & 0.8689 \\
\hline HMV & 487.433 & & & & & & & & & & 0.447 \\
\hline
\end{tabular}




\begin{tabular}{|c|c|c|c|c|c|c|c|c|c|c|}
\hline Nrs & 8.937 & & & & & & & & & 0.7033 \\
\hline Frs & 1.462 & -0.131 & -0.147 & 0.630 & & 0.158 & & & -0.188 & 0.9333 \\
\hline $\mathrm{F}$ & 2.846 & & & 1.005 & 0.447 & & & & & 0.6791 \\
\hline Wc & 0.302 & & & 0.130 & & & & & & 0.8842 \\
\hline Torque & 68.516 & & & -0.683 & & & & & & 0.7234 \\
\hline SME & 547.011 & -29.491 & & -42.760 & & 43.672 & & & & 0.6937 \\
\hline$L^{*}$ & 60.867 & -4.173 & & & & & & & & 0.9476 \\
\hline$a^{*}$ & 2688.248 & & & & 1168.523 & & 1477.176 & & & 0.4884 \\
\hline$b^{*}$ & 8.035 & 1.200 & & 0.122 & & & & -0.208 & -0.208 & 0.9862 \\
\hline 'Hue & 1.568 & & & & & & 0.0005 & & & 0.6364 \\
\hline ABTS & 9.528 & 2.853 & & & & & & & & 0.7579 \\
\hline ORAC & 36.728 & & & & & & & & & 0.6264 \\
\hline
\end{tabular}

Table 2. Regression analysis results calculated under the coded levels of extruded mixed rice and grape peel. $\beta_{\mathrm{i}}$ regression coefficients; $R^{2}$ : coefficient of determination

Even without a good correlation, one can analyse that the variable $x 1$ ( $\%$ GP) interfered in the majority of flours proximal composition responses, as can be illustrated in Pareto Diagram (Graphic 1a), as it can be analysed in ashes, proteins, lipids and carbohydrates, thus reflecting that with the insertion of fibres, such as GP, in food products, macronutrient levels show better results. For the protein response, there was also a linear relationship between the proportion of GP and temperature in the third zone of the extruder.

Table 1 also shows the results of the fibre contents for the treatments that correspond to the best results of water solubility and absorption and expansion indexes, which reflect the best technological functional characteristics of the precooked flours. Rice flour is considered a low-fibre food with a content of $0.76 \mathrm{~g}$. 100g-1 (AUGUSTO-RUIZ et al., 2003), but when mixed with undergoing extrusion process, there was an increase in the fibre content to $20.59 \mathrm{~g} .100$ $\mathrm{g}-1$, as can be observed in treatment 13. The chemical composition of the grapefruit flour is high in crude fibres, about $58 \mathrm{~g} .100 \mathrm{~g}-1$ (FERREIRA, 2012). According to ANVISA 54/2012, this flour can be considered a fibres source, since it has a content superior to that established by the legislation, of $3 \mathrm{~g} .100 \mathrm{~g}-1$. Similar results (51.1\% to $56.3 \%)$ were reported by Deng et al. (2011). The insertion of grapefruit flour, in this way, is able to add nutritional and functional value to food products.

\subsubsection{Color determination}

The extruded mixed RF and GP flour (Table 3) showed characteristic coloration of the rind of the grape, with $L$ * values ranging from 55.33 (for treatment with $23.4 \%$ inclusion of GP flour) to 69.00 (for $6.6 \%$ inclusion treatment of GP flour), being close to the middle of the scale and, according to the Hue angle $\left(13.14^{\circ}\right.$ to $\left.44.23^{\circ}\right)$. The coloration approximates of the red chroma, so the FCU presents red chroma with dark tonality. $L$ * values being statistically 
affected by the proportion of GP flour, as can be illustrated in Pareto Diagram (Graphic 1d), and $b^{*}$ affected by the proportion of GP flour, proportion of moisture and with the relation between extrusion temperature and moisture and the proportion of GP and temperature, as can be illustrated in Pareto Diagram (Graphic 1e). The dark coloration of an ingredient, in some cases, limits its use in food products, but the inclusion of dark-colored ingredients in food products has been associated by consumers with whole and therefore healthier ingredients (SELANI et al., 2016).

\subsubsection{Process response}

Table 3 shows the torque values, specific mechanical energy (SME), bulk density $(\mathrm{BD})$, radial expansion index (REI), water absorption index (WSI) and solubility index (WSI).

\begin{tabular}{|c|c|c|c|c|c|c|c|c|c|}
\hline Treatment & $\begin{array}{c}\text { Grape peel* } \\
\text { proportion (\%) }\end{array}$ & $\begin{array}{c}\text { Temperature } \\
\left({ }^{\circ} \mathrm{C}\right)\end{array}$ & $\begin{array}{c}\text { Moisture } \\
\text { Content } \\
(\%)\end{array}$ & Torque & SME & BD & REI & WAI & WSI \\
\hline 1 & 10 & 120 & 15 & 72.0 & 673.73 & 212.46 & 7.60 & 18.94 & 13.55 \\
\hline 2 & 10 & 120 & 19 & 65.5 & 541.90 & 400.01 & 4.68 & 10.49 & 9.51 \\
\hline 3 & 10 & 140 & 15 & 78.0 & 610.05 & 206.76 & 7.43 & 19.50 & 13.78 \\
\hline 4 & 10 & 140 & 19 & 73.5 & 549.50 & 403.20 & 4.58 & 17.27 & 7.68 \\
\hline 5 & 20 & 120 & 15 & 75.5 & 609.49 & 233.06 & 6.15 & 11.13 & 15.16 \\
\hline 6 & 20 & 120 & 19 & 60.0 & 557.56 & 425.73 & 3.76 & 11.15 & 10.64 \\
\hline 7 & 20 & 140 & 15 & 74.5 & 605.57 & 226.99 & 6.05 & 19.12 & 11.80 \\
\hline 8 & 20 & 140 & 19 & 56.5 & 602.48 & 374.75 & 3.61 & 18.05 & 10.15 \\
\hline 9 & 6.6 & 130 & 17 & 58.5 & 725.38 & 242.97 & 6.25 & 19.56 & 13.62 \\
\hline 10 & 23.4 & 130 & 17 & 63.0 & 545.41 & 347.02 & 4.16 & 18.44 & 11.76 \\
\hline 11 & 15 & 113.2 & 17 & 75.0 & 641.63 & 339.25 & 5.20 & 11.45 & 11.24 \\
\hline 12 & 15 & 146.8 & 17 & 76.5 & 628.94 & 270.33 & 5.22 & 34.03 & 11.55 \\
\hline 13 & 15 & 130 & 13.6 & 80.0 & 673.70 & 171.06 & 8.14 & 35.76 & 15.91 \\
\hline 14 & 15 & 130 & 20.4 & 51.0 & 533.03 & 445.54 & 3.50 & 33.25 & 9.64 \\
\hline 15 & 15 & 130 & 17 & 76.5 & 577.03 & 292.75 & 5.45 & 34.19 & 11.98 \\
\hline 16 & 15 & 130 & 17 & 70.0 & 569.18 & 246.64 & 5.95 & 11.62 & 12.09 \\
\hline 17 & 15 & 130 & 17 & 61.0 & 544.46 & 266.76 & 5.16 & 11.84 & 11.83 \\
\hline 18 & 15 & 130 & 17 & 76.5 & 534.64 & 303.90 & 5.13 & 12.13 & 10.77 \\
\hline 19 & 15 & 130 & 17 & 59.0 & 507.61 & 286.02 & 5.30 & 11.48 & 11.69 \\
\hline
\end{tabular}

Table 3. Results of technical properties for precooked mixed rice and grape peel flour according to the experimental design. *The other percentage corresponds to rice flour; Torque (N.m); SME: specific mechanical energy $\left(\mathrm{kJ} \mathrm{kg}^{-1}\right)$; BD: bulk density $\left(\mathrm{kg}^{\left.-\mathrm{m}^{-3}\right)}\right.$; REI: radial expansion index; WAI: water absorption index (g. $\left.100 \mathrm{~g}^{-1}\right)$; WSI: water solubility index (g. $\left.100 \mathrm{~g} \mathrm{~g}^{-1}\right)$. 


\subsubsection{Specific Mechanical Energy (SME)}

The SME, is related to factors which include, first of all, the composition of the food raw material, high carbohydrate, high protein, low or high fat, or high fibre will have different values and SEM. Secondly, the moisture processing, high moisture content products, will basically have lower SEM values, single or twin-screw configuration also have an influence on SEM, low shear configuration tends to have lower SEM, but it depends on processing moisture. Other factor that influences is diameter, type and number of dies as it is away to restrict the flow of the material. Sandrin et al. (2017), the adjustment of the parameters, using rice and oat blends, resulted in optimal results, such as good expansion, water absorption, although there was a small loss of lipid, which evidently may have been lost during the process. The proportionality of rice flour (RF) and grape peel (GP) (90:10, 85:15, 80:20), respectively, (Table 3), related fibre content of GP, will have an SME behaviour, according to the temperature and moisture content. The values of the extremes, by experimental design, $-\mathrm{a}(6.6 \%)$, of GP, $+a(23.4 \%)$ presented 725.38; 545.41 (kJ.kg-1), respectively. This explains why, the fibre content causes mechanical stress to decrease, of course, considering the material moisture processing, there will be some differentiations. On the other hand, considering chemical effects, according to Khanal et al., (2009), the screw speed also affect the materials components, as demonstrated in the procyanidin contents of grape seed and pomace, showing increasing results as speed increases, although in this experiment the screw speed has been maintained at $150 \mathrm{rpm}$.

\subsubsection{Torque}

In the mixtures of rice flour and grape flour, when extruded, the torque, which is important for checking mechanical stress during the extrusion process, was higher, the higher the grape skin content. (Table 3). However, among the treatments, it was not significant ( $p>$ 0.05). Altan et al, (2008) have observed a similar effect by extruding the mix of barley - tomato pomace. This was significant in the treatments with higher level of grape peel inclusion $(p<$ 0.05).

With higher level of fibre inclusion, the grape peel particles have a tendency to disrupt the flow of the starch melt imparting greater resistance to flow resulting in higher torque. Torque decreased as the screw speed increased. Increased screw speed leads to increase in shear rate and decreased residence time. This in turn will help reduce the torque.

\subsection{Technological characterization of the extrudates}

\subsubsection{Radial Expansion index (REI) Ratio and Bulk density (BD)}

For all treatments with GP flour inclusion, there was an increase in screw speed, which increased REl, although not statistically significant for all treatments $(p>0.05)$. For treatments with inclusion of $20 \%$ grape peel flour, there was a slight decrease in REI ( $p>$ 
0.05) (Table 3). This suggests that dew at lower inclusions and with smaller particle, sizes can increase expansion during extrusion. This may indicate that, at lower concentrations, there was a uniform distribution of fibre in the starch matrix, allowing expanding and reducing premature cell rupture in the extrudates (GUAN et al., 2004). In addition, finer particle size fibres provide more nucleation sites that can result in more air cells being formed and greater overall expansion.

With $15 \%$ of bagasse inclusion, depending on the other process variables, such as moisture and temperature, ER decreased significantly $(p<0.05)$. The bulk density is an important feature of the expanded extrudates that, in general, is inversely proportional to the expansion index. Samples BD with the lowest level of grape peel flour inclusion presented the lowest values.

This can be attributed to the fact that the apparent density of mixed flour extruded with lower inclusion level of grape peel flour was lower in comparison with the higher levels. The mixed flour with higher inclusion levels of smaller grape peel flour was distributed more evenly in the starch matrix, leading to a lower density product at the same inclusion level. An increase in BD with an increase in the level of grape peel flour was due to the presence of more fibre particles that have a more pronounced ability to break down the cell walls before the gas bubbles expand to their full potential. Similar results were observed of extrusion of barley with grape marc (ALTAN et al., 2008) and corn flour with sugar beet fibre. There was an inconstancy of results due to the

\subsection{2 combination of three variables in the process}

Product expansion depends mainly on the composition of the material and the processing conditions, low percentages of processing moisture, usually generate higher exposure values Peska et al. (2016). It is a parameter dependent on the water vaporization intensity and flow properties of the molten starch.

Water is not a limiting factor, with the rheological properties of the molten material being the main variables, since the longitudinal and radial expansions are dependent on the viscosity and elasticity of the molten material, respectively. Usually, the expansion expressed by the ratio of the cross-sectional area of the extrudates by die diameters of extruder. It has been observed that in expanded extruded products, air occupies 85 to $92 \%$ of the total volume, except for samples extruded at low temperature. In this way, extrudates with density values in the range of 0.04 to $0.38 \mathrm{~g} . \mathrm{cm}-3$ are obtained.

The maximum degree of expansion can be predicted based on the starch content. In pure starches, (depending on the starch source and its composition on amylose and amylopectin) the expansion may reach $500 \%$, followed by $400 \%$ whole grains and $200-300 \%$ oleaginous seeds. The starch content in these materials is $100,65-78$ and $0-10 \%$, respectively. According to some references, the maximum limit of starch in a product for expansion to occur 
is 60 to $70 \%$. The increase in the level of damaged starch in the raw ingredients leads to products with pores, soft texture, greater solubility and sticky character when eaten.

According to Table 3, the calculated BD values ranged between 171.06 (treatment 13) and 445.54 (treatment 14) kg.m-3, being statistically affected by the proportion of grape peel flour, as can be illustrated in Pareto Diagram (Graphic 1b). In expanded products, it is desirable that the densities be low, which have been achieved in combinations of low moisture extrusion. In treatment 14, where there is interaction of higher level of extrusion moisture, contributed to an increase in extrudates density. The calculated REI of the extrudates varied between 3.504 (treatment 13) and 8.317 (treatment 14), being statistically affected by the extrusion variables moisture and proportion of grape peel flour, as can be illustrated in Pareto Diagram (Graphic 1c).

\subsubsection{Water Absorption and solubility Properties}

Hydration properties play an important role in protein-water and carbohydrate-water interactions. The main functional properties of extruded starches, when dispersed in excess of water, are water absorption and water solubility. The water absorption index (WAI) is a measure of the degree of modification of the starch, denaturation of the proteins and macromolecular formation and complexes. The water solubility index (WSI) reflects the amount of soluble polysaccharides released from the granular structures in excess water (AL-RABADI et al., 2011).

As is known, native starch hardly absorbs water at room temperature and its contribution to viscosity is practically zero. Meanwhile, the extruded starch absorbs water rapidly, forming a slurry at room temperature, without any heating. The degree of conversion of the starch during the extrusion process was studied by the technique of absorption and water solubility indices. The absorption of water molecules begins by fixing them to the polar zones of the polymers until they reach their swelling. The swelling properties encompass an increase of the hydrogen bonds between water molecules and hydroxyl groups of the polymers. In starch, this property is primarily the result of the molecular structure of amylopectin, with amylose acting as a diluent (SRICHUWONG et al., 2005). The fibre has a lower potential for swelling due to its greater insolubility (BEMILLER and HUBER 2008).

During the extrusion process, the proteins are affected by both the heat effect and the mechanical shear. Heat causes denaturation and protein aggregation, whereas mechanical shear causes dissociation / depolymerisation (FANG et al., 2013). These transformations may decrease the surface of the protein molecule and the availability of polar groups to fix water. In proteins of very compact structure dissociation and cleavage of molecules occurs, it being possible that peptide bonds and previously inactive polar side chains, reach the protein surface, improving the hydration properties.

The results of WAI and WSI are presented in Table 3. Extruded treatment flour 13 
(15\% grapefruit, $130^{\circ} \mathrm{C}$ and $13.6 \%$ moisture) revealed the highest WAI, reflecting that lower moisture increases the absorption of water of the product, and also with the transformation of insoluble fibres into soluble fibres. Treatment 14 (15\% grape peel, $130^{\circ} \mathrm{C}$ and $20.4 \%$ moisture) revealed the lowest WSI, reflecting that water solubility decreases with increasing moisture in the process. The treatment in which the concentration of grape peel was higher (treatment 10) had its WAI much lower than the treatment 13, $18.44 \mathrm{~g} .100 \mathrm{~g}-1$, reflecting that the higher fibre concentration leads to a lower water absorption in the product.

The starch granules were heated, swollen and crosslinked to disrupt the grape peel fibre particles in the formation of the starch fibre matrix, in addition to starch dextrinization, resulting in low WSI (Kumar et al. 2010). The high mechanical shear caused a breakdown of starch to small molecules with greater solubility (ALTAN et al., 2009). This characteristic justifies its use in instant foods. The combination of process temperature and moisture content generated inconsistent results.

Low WAI values reflect the restricted access of water to extruded starches, attributed to a compact structure. On the other hand, the solubility may be related to the lower molecular weight of the starch components, which can be separated very easily from each other due to the limited interaction between them.

The WSI and WAI values can be used to estimate the suitability of the use of extruded starch products in suspensions or solutions. Applications in media with a limited amount of water are based on these functional properties and often involve hydrogen bonding ability.

\subsubsection{Pasting Properties and Mechanical Properties}

Starch recrystallization chains are called retrogradation. This process is irreversible and is usually attributed mainly to the compaction of the amylose chains, where during the gelatinization many amylose molecules leave the interior of the granule and are suspended in the medium and, upon cooling, these molecules unwind and interact with each other to form hydrogen bonds, and then the water exits between the molecules, which then become compacted (HOOVER, 1995).

The retrogradation is responsible for the shrinkage, syneresis and hardening of starch gels preserved for a certain period, mainly at the refrigeration temperature. These effects are most evidenced when the gel is frozen and thawed several times. In foods such as breads, sauces and puddings, the occurrence of retrogradation is undesirable and should be avoided, but is desirable in forming insoluble films, for example (HOOVER, 1995).

According to Table 4, the cold maximum viscosity (CMV) ranged from 308.5 (treatment 10) to 522.5 (treatment 14) cP, and it could be verified that it was smaller with the increment of grapefruit flour $(23.4 \%)$ and higher when the moisture content increased $(20.4 \%)$. The breakdown ranged from 70.6 (treatment 2) to 551.5 (treatment 9) cP, while the tendency for setback ranged from 130.0 (treatment 5) to 472.5 (treatment 4) cP. Hot maximum viscosity 
(HMV) ranged from 95.5 (treatment 2) to 672.0 (treatment 9) $\mathrm{cP}$.

The increase in extruder jacket temperature causes an increase in the temperature of the product in the same order, mainly by conduction, which leads to a decrease in viscosity, without significant changes in residence time.

Consequently, the increase in jacket temperature tends to produce a more processed product, but to a limited extent, because the decrease in viscosity causes a decrease in heat generation (ASCHERI and CARVALHO 2014; BERRIOS; ASCHERI; LOSSO, 2012). This behaviour was confirmed in the processing of rice flour and grape rind in the single screw extruder, observing the decrease in the intrinsic viscosity of the product with increasing the jacket temperature (from 120 to $140^{\circ} \mathrm{C}$ ), through Table 4.

\begin{tabular}{cccccccccccc}
\hline Treatment & $\begin{array}{c}\text { Grape pee }{ }^{*} \\
\text { proportion } \\
(\%)\end{array}$ & $\begin{array}{c}\text { Temperature } \\
\left({ }^{\circ} \mathrm{C}\right)\end{array}$ & $\begin{array}{c}\text { Moisture } \\
\text { Content } \\
(\%)\end{array}$ & CMV & Breakdown & Setback & HMV & Nrs & Frs & F & Wc \\
\hline 1 & 10 & 120 & 15 & 325.0 & 170.0 & 348.0 & 312.0 & 10.16 & 1.01 & 1.87 & 0.20 \\
2 & 10 & 120 & 19 & 185.5 & 70.6 & 381.0 & 95.5 & 8.30 & 2.72 & 5.11 & 0.61 \\
3 & 10 & 140 & 15 & 651.0 & 489.5 & 300.0 & 609.0 & 11.87 & 0.90 & 1.99 & 0.17 \\
4 & 10 & 140 & 19 & 398.0 & 93.5 & 472.5 & 419.0 & 7.55 & 2.63 & 4.21 & 0.54 \\
5 & 20 & 120 & 15 & 336.0 & 259 & 130.0 & 339.0 & 12.41 & 0.89 & 2.64 & 0.22 \\
6 & 20 & 120 & 19 & 409.0 & 320.5 & 216.5 & 439.5 & 8.42 & 2.14 & 4.11 & 0.46 \\
7 & 20 & 140 & 15 & 396.5 & 284.5 & 169.5 & 396.5 & 12.39 & 0.81 & 2.37 & 0.20 \\
8 & 20 & 140 & 19 & 401.5 & 310.0 & 212.5 & 460.0 & 9.30 & 1.51 & 3.24 & 0.34 \\
9 & 6.6 & 130 & 17 & 662.0 & 551.5 & 330.0 & 672.0 & 9.26 & 1.55 & 2.68 & 0.30 \\
10 & 23.4 & 130 & 17 & 308.5 & 277.0 & 160.5 & 341.5 & 12.32 & 1.63 & 5.83 & 0.47 \\
11 & 15 & 113.2 & 17 & 490.5 & 388.5 & 287.5 & 510.0 & 5.20 & 2.30 & 2.76 & 0.48 \\
12 & 15 & 146.8 & 17 & 346.0 & 309.0 & 222.0 & 397.0 & 9.72 & 1.65 & 3.40 & 0.37 \\
13 & 15 & 130 & 13.6 & 326.0 & 268.0 & 154.5 & 324.0 & 9.68 & 0.55 & 1.38 & 0.14 \\
14 & 15 & 130 & 20.4 & 522.5 & 404.0 & 344.5 & 565.0 & 9.52 & 2.45 & 4.90 & 0.50 \\
15 & 15 & 130 & 17 & 478.5 & 383.5 & 245.0 & 488.5 & 8.99 & 1.40 & 2.56 & 0.30 \\
16 & 15 & 130 & 17 & 409.5 & 330.0 & 236.5 & 418.5 & 9.01 & 1.37 & 2.68 & 0.28 \\
17 & 15 & 130 & 17 & 480.5 & 336.5 & 230.5 & 492.0 & 9.47 & 1.49 & 2.91 & 0.31 \\
18 & 15 & 130 & 17 & 462.5 & 356.0 & 256.5 & 516.5 & 9.24 & 1.47 & 2.80 & 0.30 \\
19 & 15 & 130 & 17 & 491.5 & 353.5 & 238.5 & 505.5 & 8.12 & 1.47 & 2.74 & 0.31 \\
\hline
\end{tabular}

Table 4. Results of pasting properties and mechanical properties for precooked mixed rice and grape peel flour according to the experimental design. * The other percentage corresponds to rice flour; CMV: cold maximum viscosity (cP); Breakdown: break of viscosity (cP); Setback: tendency to retrograde (cP); HMV: hot maximum viscosity (cP); Nrs: frequency of structural ruptures $\left(\mathrm{mm}^{-1}\right)$; Frs: specific breaking force $(\mathrm{N})$; F: compression force $(\mathrm{N})$; Wc: work of crocance (N.mm). 
In the extruded flours, a considerable reduction in viscosity values is observed throughout the profile. At the beginning of pasting viscosity determination, a certain water absorption capacity is observed which increases the past viscosity, being characteristic starch processed by thermoplastic extrusion and thus subjected to shear. The mixture with the highest moisture content, $20.4 \%$ (treatment 14 ), showed a marked viscosity peak in the temperature increase phase, which may indicate the presence of starch with a certain molecular integrity capable of swelling with increasing temperature, typical of raw starch. In the case of flour with higher fibre content, for example, $17 \%$ (treatment 10 ), the lower paste viscosity was observed at $25^{\circ} \mathrm{C}$, which indicates greater breaking of the starch granules by the greater shear.

It was also observed that the retrogradation of the extruded starch pastes varied according to the processing moisture content of the rice flour and grape rates. The blend under low moisture conditions, the shear occurs due to the higher solids content inside the extruder, which leads to higher SME by increasing viscosity (Table 3).

The regression variables for the viscosity properties (Table 2) indicated that the second-order polynomial model did not have a good correlation for the responses $(\mathrm{R} 2<0.90)$ and was not valid for predictive purposes $(p<0.05)$.

An expanded extrudates is a porous material, where the voids are called air cells. The distribution of cell size, organization and cell wall thickness determine the mechanical and sensory properties of the extrudates. The burst strength of air cells is a measure of cell wall resistance and has been well established to correlate with $\mathrm{REI}$, indicating that increase in pore size, along with a decrease in cell wall thickness, results in extrudates of structure weak (DOGAN and KARWE, 2003).

The instrumental texture analysis was performed with the objective of evaluating the "hardness" parameter of the extrudates, by means of the determination of the maximum shear force $(\mathrm{N})$.

According to Table 4, the calculated values of Nrs ranged from 5.20 (treatment 11) to 12.41 (treatment 5) $\mathrm{mm}-1$. The calculated Frs of the extrudates ranged from 0.55 (treatment 13) to 2.72 (treatment 2) N, while F ranged from 1.38 (treatment 13) to 5.83 (treatment 10) N. The calculated $\mathrm{W}$ varied from 0.14 (treatment 13) at 0.61 (treatment 2) N.mm. The regression analysis of the texture properties of pre-cooked mixed rice and grape rind snacks (Table 2) indicated that the second order polynomial model correlated well only with the experimental data of Frs (R2 > 0.90). The other data (Nrs, F and Wc) had no good correlation and were not valid for predictive purposes $(p<0.05)$. Frs was linearly related to the proportion of grapemeal, extrusion temperature and moisture content with the proportion of grape-meal, and quadratically with temperature, moisture and temperature and rates of grape-meal. The Pareto diagram and the response surfaces, presented in Graph 1, further illustrate these facts. 


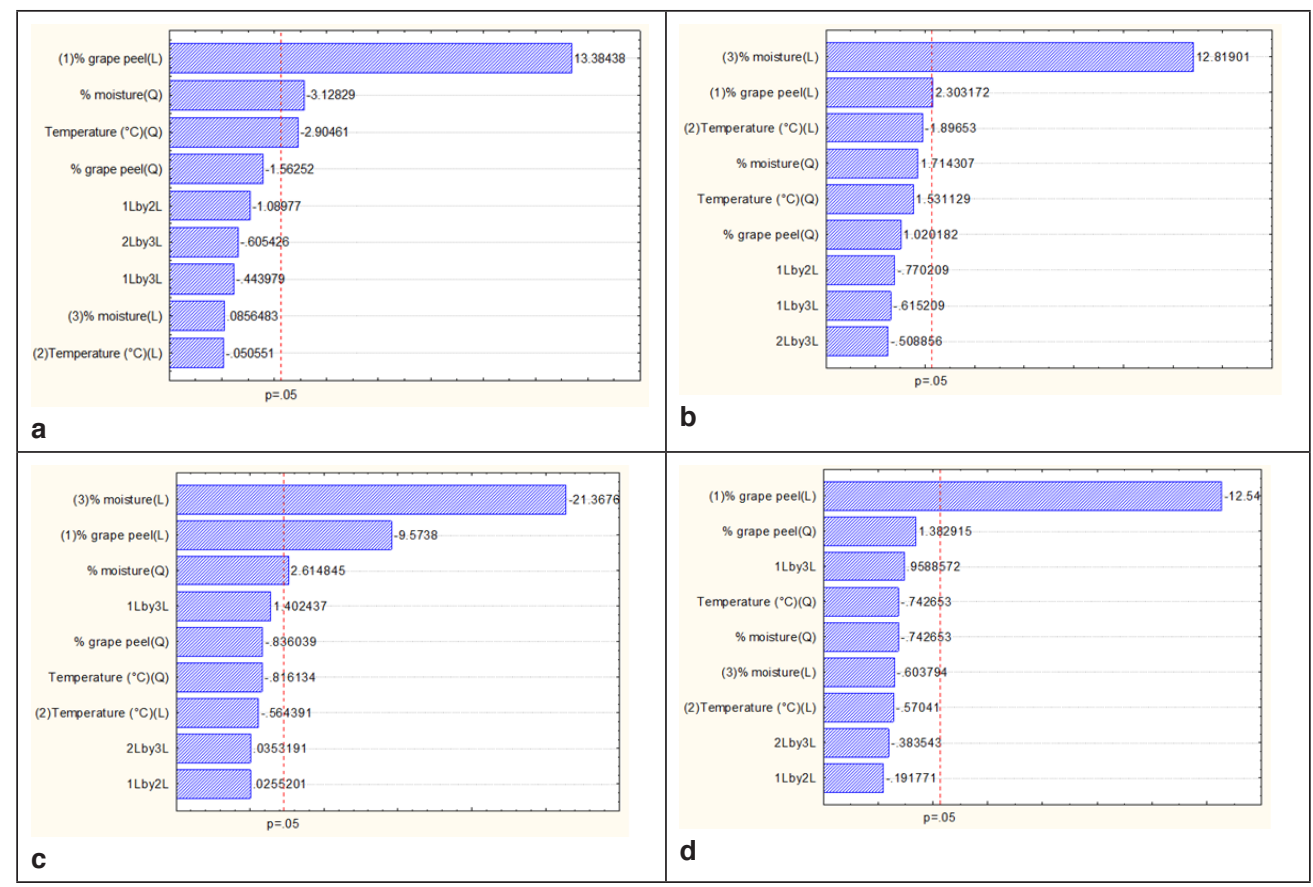

Graphic 1. Pareto diagrams for results: asches, bulk density (BD), radial expansion index (REI), $L^{*}$ and $b^{*}$ of extrudates. Grafic 1a) Pareto diagrams for the results of ashes (g. 100 $\mathrm{g}-1)$, according to the regression coefficients. Equation: $Y=1,614+0,317 x \_1-0,063 x \_2^{\wedge} 2$ $0,069 x \_3^{\wedge} 2$; Grafic 1b) Pareto diagrams for the results of BD (kg.m-3), according to the regression coefficients. Equation: $Y=299,747+15,603 x \_1+0,86,845 x \_3$; Grafic 1c) Pareto diagrams for the results of $\mathrm{REI}$, according to the regression coefficients. Equation: $Y=5,310-$

0,604x_1-1,348x_3; Grafic 1d) Pareto diagrams for the results of $L^{*}$, according to the regression coefficients. Equation: $Y=60,867-4,173 x \_1$; Grafic 1e) Pareto diagrams for the results of $b^{*}$, according to the regression coefficients. Equation: $Y=8,035+1,200 x \_1+0,122 x \_3-$ 0,208x_1 x_2-0,208x_1 x_3.

\subsection{Determination of the antioxidant capacity, phenolic compounds, anthocyanins of grape peel flour and extruded products}

The antioxidant capacity of precooked rice, grape rind and grapeseed meal was expressed by the parameters, including the removal of a peroxyl radical (ORAC) and the removal capacity of organic radical (ABTS -2,20-azino-bis (3-ethylbenzthiazoline-6-sulfonic acid).

In the ABTS radical sequestration test, ABTS + $\bullet$ is first produced by the reaction with potassium persulfate in which it is green. When this radical is mixed with the antioxidant, the radical is reduced to $A B T S$ with a consequent decrease in absorbance at $734 \mathrm{~nm}$ (GUEDES et al., 2013), and the extent of the reduction depends on the duration of the reaction, the intrinsic antioxidant activity and concentration in the sample (GUEDES et al., 2013).

According to Table 5, it is possible to verify that, according to the ORAC method, the antioxidant capacity ranged from 9.313 (treatment 9) to 36.996 (treatment 16 - center point) 
mol Trolox. g-1, whereas by the ABTS method, the antioxidant capacity ranged from 0.942 (treatment 9) to 11.772 (treatment 7) mol Trolox. g-1. For the purpose of comparison, the antioxidant capacity of the grape hull flour (raw) was determined, and, according to the ORAC method, it was $310.046 \mu \mathrm{mol}$ Trolox. $\mathrm{g}-1$ and, by the ABTS method, $43.794 \mu$ mol Trolox $\mathrm{g}-1$, which resulted in the same extrusion product still retaining $11 \%$ of its antioxidant capacity according to the ORAC method and $26 \%$ according to the ABTS method. The treatments with the highest proportion of grapefruit flour had the highest values of antioxidant capacity.

The regression analysis for antioxidant capacity for precooked rice flour and grape rind (Table 2) indicated that the second-order polynomial model did not correlate well with the experimental data ORAC and ABTS $(\mathrm{R} 2<0.90)$, and were not valid for predictive purposes $(p<0.05)$.

\begin{tabular}{|c|c|c|c|c|c|c|c|}
\hline Treatment & $\begin{array}{c}\text { Grape peel* } \\
\text { proportion (\%) }\end{array}$ & $\begin{array}{c}\text { Temperature } \\
\left({ }^{\circ} \mathrm{C}\right)\end{array}$ & $\begin{array}{c}\text { Moisture Content } \\
(\%)\end{array}$ & ORAC & ABTS & $\begin{array}{l}\text { Total phenol } \\
\text { compounds }\end{array}$ & Anthocyanins \\
\hline 1 & 10 & 120 & 15 & 15.54 & 4.495 & & \\
\hline 2 & 10 & 120 & 19 & 32.54 & 1.665 & 284.45 & 102.23 \\
\hline 3 & 10 & 140 & 15 & 15.40 & 7.832 & & \\
\hline 4 & 10 & 140 & 19 & 9.81 & 4.585 & & \\
\hline 5 & 20 & 120 & 15 & 26.42 & 6.909 & & \\
\hline 6 & 20 & 120 & 19 & 36.43 & 9.220 & & \\
\hline 7 & 20 & 140 & 15 & 32.49 & 11.772 & & \\
\hline 8 & 20 & 140 & 19 & 30.08 & 12.151 & 249.12 & 86.9 \\
\hline 9 & 6.6 & 130 & 17 & 9.31 & 0.942 & & \\
\hline 10 & 23.4 & 130 & 17 & 37.70 & 11.341 & 267.04 & 91.95 \\
\hline 11 & 15 & 113.2 & 17 & 22.78 & 4.747 & & \\
\hline 12 & 15 & 146.8 & 17 & 23.44 & 4.730 & & \\
\hline 13 & 15 & 130 & 13.6 & 30.38 & 6.154 & & \\
\hline 14 & 15 & 130 & 20.4 & 17.81 & 6.570 & & \\
\hline 15 & 15 & 130 & 17 & 33.67 & 7.153 & & \\
\hline 16 & 15 & 130 & 17 & 37.00 & 13.572 & & \\
\hline 17 & 15 & 130 & 17 & 40.57 & 6.876 & & \\
\hline 18 & 15 & 130 & 17 & 32.74 & 11.127 & & \\
\hline 19 & 15 & 130 & 17 & 31.28 & 9.267 & & \\
\hline $\begin{array}{c}\text { Grape } \\
\text { peel }\end{array}$ & & & & & & 1772 & 1731 \\
\hline flour $^{\star \star}$ & & & & 310.05 & 43.794 & & \\
\hline
\end{tabular}

Table 5. Antioxidant capacity by ABTS and ORAC and average contents of phenolic compounds and anthocyanins for precooked mixed rice and grape peel flour according to the experimental design. * The other percentage corresponds to rice flour; ABTS and ORAC expressed in $\mu \mathrm{M}$ Trolox eq /g DW. 


\subsubsection{Total phenol compounds and Anthocyanins}

Table 5 shows the results of total phenolic compounds and anthocyanins for extrusion temperature zones and for grapefruit flour. The mean triplicates of the content of total phenolic monomeric compounds anthocyanins extracted from the samples expressed in gallic acid equivalent per $100 \mathrm{~g}$ of sample and equivalent of malvidin-3-glycoside per $100 \mathrm{~g}$ of sample, respectively.

It is possible to verify that there was a decrease of the values with the increase of the temperature. When the results compared to those of the still raw grapefruit flour, it is known that the extrusion process affected the concentration of these compounds, with the extrudates remaining at about $16 \%\left(120^{\circ} \mathrm{C}\right), 15 \%\left(130^{\circ} \mathrm{C}\right)$ and $14 \%\left(140^{\circ} \mathrm{C}\right)$ of phenolic compounds, and $5.9 \%\left(120^{\circ} \mathrm{C}\right), 5.3 \%\left(130^{\circ} \mathrm{C}\right)$ and $5 \%\left(140^{\circ} \mathrm{C}\right)$ anthocyanins. Compared to the treatment with lower temperature $\left(113.2^{\circ} \mathrm{C}\right)$ and higher temperature $\left(146.8^{\circ} \mathrm{C}\right)$, no significant difference in antioxidant capacity was observed. Thus, even with the extrusion process, it is still possible to have antioxidant capacity in the products, since the residence time in the equipment is short. The processing effect on the antioxidant capacity of the grape is quite complex due to the diversity of the present compounds.

The contents of phenolic compounds and anthocyanins were analysed for the best treatments at 120,130 and $140^{\circ} \mathrm{C}$ in order to analyse the effect of the extrusion process. Extrusion processing in rice flour and whole grains of total phenolic content affected the total phenolic content, as can be observed in Table 5, but showed intermediate values of phenolic compounds and anthocyanins.

It may be that the phenols have been protected by the starch matrix and thus were not totally lost during the extrusion processing. It is also important to consider that during the extrusion processing, the residence time of the materials in the extruder is very short (LOPES et al., 2016). The combined effects of protection of phenolic content by starch coating and short residence time should not result in significant loss of phenolic content. Increasing the proportion of grape peel flour inevitably increased the total phenolic of extrudates. Processing for the preparation of the extruded rice flour and grape peel decreased its antioxidant capacity, and anthocyanins were more affected than total phenolic compounds because they were more sensitive to heat.

\section{I CONCLUSION}

Extrusion is a technology useful in the processing of grape marc as a way of preserving its nutritional quality. The processing of the pre-cooked mixed flour of rice and grape peel under various processing conditions (rates of grape peel/rice flour, moisture and temperature), resulted in effects on the various process-dependent variables and physicalchemical properties. The fraction of the peel was increased with the purpose of enriching the rice flour, which, although possessing energetic potential, but low in fibre, provides a 
contribution of dietary antioxidant fibres. The use of extruded flour for obtaining certain foodstuffs is advantageous, since the extrusion process leads to the pre-cooking of the starch granules, causing loss of molecular order and complete degradation of the polymers, with the formation of fragments highly soluble.

Therefore, suspensions of extruded pre-cooked flours are capable of rapidly increasing their viscosity, exhibiting a low agglomeration tendency, since the starch granules were modified, and showed great swelling power in cold and hot, and it is highly recommended for the development of instant food products. There is a further need to investigate the active interactions between the fibers and the starch polymers during extrusion processing. This can uncover new areas of research that can benefit the food industry significantly.

Understanding these interactions can lead to the development of higher fibre expanded starch extrudates with comparable quality or better than starch extrudates. In this context, it can be concluded that the process of obtaining food products from pre-cooked mixed rice and grape rind flour is capable of increasing the value added of the product, as well as encouraging the rational consumption of agroindustry by-products in food human. In this way, it can be affirmed that the mixed flours obtained, in agreement with the processing conditions, can be obtained flours for different uses in the food preparation, thus allowing the ingestion of fibres and antioxidant compounds.

\section{ACKNOWLEDGMENTS}

Embrapa Food Agroindustry for admitting an internship, during the postgraduate degree. Coordination for the Improvement of Higher Education Personnel (CAPES); The Brazilian National Council for Scientific and Technological Development (CNPq) and Fundação Carlos Chagas Filho de Amparo à Pesquisa do Estado do Rio de Janeiro - FAPERJ, for support the Post-graduate stricto sensu Programs. Compliance with Ethical Standards Conflict of Interest, The authors attest that there are no interests that competed with the objective, interpretation, and presentation of the results.

\section{REFERENCES}

AL-RABADI, G. J.; TORLEY, P. J.; WILLIAMS, B. A.; BRYDEN, W. L.; GIDLEY, M. J.. Particle size of milled barley and sorghum and physico-chemical properties of grain following extrusion. Journal of Food Engineering, v. 103, n. 3, p. 464-472, 2011, DOI: 10.1016/j.jfoodeng.2010.11.016.

ALTAN, A.; MCCARTHY, K. L.; MASKAN, M. Evaluation of snack foods from barley-tomato pomace blends by extrusion processing. Journal of Food Engineering, v. 84 n.2, p. 231-242, 2008, DOI: 10.1016/j.jfoodeng.2007.05.014

ALTAN, A.; MCCARTHY, K. L.; MASKAN, M. Effect of extrusion process on antioxidant activity, total phenolic and b-glucan content of extrudates developed from barley-fruit and vegetable by-products. International Journal of Food Science and Technology, v. 44, p. 1263-1271, 2009. DOI: 10.1111/j.1365-2621.2009.01956.x 
ANDERSON, R. A.; CONWAY, H. F.; PFEIFER, V. F.; AND GRIFFIN, E. L. Gelatinization of corn grift by roll and extrusion cook. Cereal Science Today, Saint Paul, v. 14, n. 1, p. 4-11, 1969.

ANVISA. Ministério da Saúde. Resolução no 54. Dispõe sobre o Regulamento Técnico sobre Informação Nutricional Complementar. Diário Oficial da União, Brasília. 2012.

AOAC International. Method 990.03, 993.13, 997.09. Official Methods of Analysis of AOAC International. 18ed. 3a rev. Gaithersburg, MD, USA. 2010.

ALVAREZ-MARTINEZ, L.; K. P. KONDURY.; J. M. HARPER. A General Model for Expansion of Extruded Products. Journal of Food Science, v. 53, n. 2, p. 609-615, 1988. doi:10.1111/j.1365-2621.1988.tb07768.x

APPROVED METHODS OF THE AMERICAN ASSOCIATION OF CEREAL CHEMISTS - AACC. 10th ed. Methods 44-15 A, 44- 40. The Association, St. Paul, MN, US: AACC. 2000.

ASCHERI, D. P. R.; BOÊNO, J. A.; BASSINELLO, P. Z.; ASCHERI, J. L. R. Correlation between grain nutritional content and pasting properties of pre-gelatinized red rice flour. Rev. Ceres, v.59 n.1, 2012, DOI: 10.1590/S0034-737X2012000100003.

ASCHERI, J. L. R.; CARVALHO, C. W. P. Tecnologia de extrusão: uma ferramenta para o desenvolvimento de produtos. In: Tendências e Inovações em Ciência, Tecnologia e Engenharia de Alimentos.1 ed. São Paulo: Atheneu, v.1, p., 2014, p. 123-146.

AUGUSTO-RUIZ, W.; BONATO, R. S.; RISSO, F.A.V.; ARRIECHE, L.S. Caracterização da farinha pré-gelatinizada de arroz integral produzida a partir de grãos quebrados. Vetor, Rio Grande, v. 13, p. 25-46, 2003.

BEMILLER, J. N.; HUBER, K. C. Carbohydrates. In S. DAMORAN; K. L. PARKIN; O. R. FENNEMA (Eds.), Fennema's food chemistry (4 ${ }^{\text {th }}$ ed., p. 75-130), 2008. CRC Press, Boca Raton.

BERRIOS, J. D. J.; ASCHERI, J. L. R.; LOSSO, J. N. (2012). Extrusion Processing of Dry Beans and Pulses. In: M. SIDDIQ AND M. A. UEBERSAX, Eds. Dry Beans and Pulses Production, Processing and Nutrition Blackwell Publishing Ltd., Oxford, UK., 2012. DOI: 10.1002/9781118448298.ch8

BRENNAN, C.; BRENNAN, M.; DERBYSHIRE, S.; TIWARI, B.K. Effects of extrusion on the polyphenols, vitamins and antioxidant activity of foods. Trends in Food Science and Technology, v. 22 n.10 p. 570-575, 2011. DOI: 10.1016/j.tifs.2011.05.007

BRNCIC, M.; BOSILJKOV, T.; UKRANINCZYK, M.; TRIPALO, B.; BRNCIC, S. R.; KARLOVIC, S. Influence of whey protein addition and feed moisture content on chosen physicochemical properties of directly expanded corn extrudates. Food and Bioprocess Technology, v. 4 n. 7, p. 1296-1306, 2011. DOI: 10.1007/s11947-009-0273.

DENG, Q.; PENNER, M. H.; ZHAO, Y. Chemical composition of dietary fiber and polyphenols of five different varieties of wine grape pomace peels. Food Research International, v. 44 p. 27122720, 2011. DOI: 10.1016/j.foodres.2011.05.026. 
DIAMANTE, L. M.; SAVAGE, G. P.; VANHANEN, L. Optimisation of vacuum frying of gold kiwifruit slices: application of response surface methodology. Int J Food Sci Technol. v. 47, p. 518-524, 2012. DOI: 10.1111/j.1365-2621.2011.02872.x

DOGAN, H.; KARWE, M. V. Physicochemical properties of quinoa extrudates. Food Science and Technology International, v. 9 n. 2, p. 101-114, 2003. DOI: 10.1177/1082013203009002006

FANG, Y.; ZHANG, B.; WEI, Y.; LI, S. Effects of specific mechanical energy on soy protein aggregation during extrusion process studied by size exclusion chromatography coupled with multi-angle laser light scattering. Journal of Food Engineering, v. 115, n. 2, p. 220-225, 2013. DOI: 10.1016/j.jfoodeng.2012.10.017

FAOSTAT. Online Statistical Service (Food and Agriculture Organization (FAO), 2016) http://faostat3. fao.org.

FERREIRA, L. F. D.; PIROZI, M. R; RAMOS, A. M.; PEREIRA, J. A. M.. Modelagem matemática da secagem em camada delgada de bagaço de uva fermentado. Pesquisa Agropecuária Brasileira, Brasília, DF, v. 47, n. 6, p. 855-862, 2012. DOI: 10.1590/S0100-204X2012000600017.

GEORGÉ, S.; BRAT, P.; ALTER, P.; AMIOT, M. J. Rapid determination of poliphenols and vitamin C in plant-derived products. Journal of Agricultural and Food Chemistry, v. 53, p. 1370-1373, 2005. DOI: 10.1021/jf048396b.

GONZALEZ-NEVES, G.; FAVRE, G.; GIL, G.; FERRER, M.; DARWIN, C. Effect of cold prefermentative maceration on the color and composition of young red wines cv. Tannat. J Food Sci Technol.; v. 52, n.6, p. 3449-3457, 2015. DOI: 10.1007/s13197-014-1410-y

GUAN, J.; FANG, Q.; HANNA, M. Selected functional properties of extruded starch acetate and natural fibers foams. Cereal Chemistry, v. 81 n. 2, p. 199-206, 2004. DOI: 10.1094/ CCHEM.2004.81.2.199.

GUEDES, A. C.; AMARO, H. M.; GIÃO, M. S.; MALCATA, F. X. Optimization of ABTS radical cation assay specifically for determination of antioxidant capacity of intracellular extracts of microalgae and cyanobacteria. Food Chemistry, v. 138, n. 1, p. 638-643, 2013. DOI: 10.1016/j. foodchem.2012.09.106.

HOOVER R. Starch retrogradation. Food Reviews International, 11:2, 331-346, 1995. DOI: $10.1080 / 87559129509541044$

JACKSON, R. S. Wine Science - Principles and applications. 3. ed. Amsterdam: Elsevier Inc., 2008. 789p.

JENG, T. L.; LAI, C. C.; HO, P. T.; SHIH, Y. J.; SUNG, J. M. Agronomic, molecular and antioxidative characterization of red- and purple-pericarp rice (Oryza sativa L.) mutants in Taiwan. Journal of Cereal Science, v. 56, p. 425-431, 2012. DOI: 10.1016/j.jcs.2012.05.015

KHANAL, R.C.; HOWARD, L.R.; PRIOR, R.L. Procyanidin Content of Grape Seed and Pomace, and Total Anthocyanin Content of Grape Pomace as Affected by Extrusion Processing. Journal of Food Science, v. 74, n. 6, p. 174-182, 2009. DOI: 10.1111/j.1750-3841.2009.01221.x 
KUMAR, M.; KUMAR, D.; PANDEY, L. K.; AND GAUR, J. P. Methylene blue sorption capacity of some common waste plant materials. Chem. Eng. Comm. V. 197, p. 1435-1444, 2010. DOI: $10.1080 / 00986441003626193$.

LEE J.; DURST, R. W.; WROLSTAD, R. E. Determination of total monomeric anthocyanin pigment content of fruit juices, beverages, natural colorants, and wines by the $\mathrm{pH}$ differential method: collaborative study. J. AOAC INT., v. 88, n. 5, p. 1269-1278, 2005.

LLOBERA, A.; CAÑELLAS, J. Dietary fibre content and antioxidant activity of Manto Negro red grape (Vitis vinifera): pomace and stem. Food Chemistry, v. 101, n. 2, p. 659-666, 2007. DOI: 10.1016/j.foodchem.2006.02.025.

LOPES, M. F.; SANTOS, L.; CHOUPINA, A. A extrusão em tecnologia alimentar: aplicações, características dos produtos, composição e tendências futuras. Rev. de Ciências Agrárias, Lisboa , v. 39, n. 1, p. 04-14, 2016. DOI: 10.19084/RCA14103

LUQUE-RODRÍGUEZ, J. M.; LUQUE DE CASTRO, M. D.; PÉREZ-JUAN, P. Extraction of fatty acids from grape seed by superheated hexane. Talanta, v. 68, p. 126-130, 2005. DOI: 10.1016/j. talanta.2005.04.054

MONRAD, J.K.; HOWARD, L.R.; KING J.W. Subcritical solvent extraction of anthocyanins from dried red grape pomace. Journal of Agricultural and Food Chemistry, v. 58, p. 2862-2868. DOI: $10.1021 / \mathrm{jf} 904087 \mathrm{n}$

PATEL, J. R.; PATEL, A. A.; SINGH, A. K. Production of a protein-rich extruded snack base using tapioca starch, sorghum flour and casein. Journal of Food Science and Technology, 53(1), 71-87, 2016. DOI: 10.1007/s13197-015-2012-z

PATHAK N.; KOCHHAR, A. Extrusion Technology: Solution to Develop Quality Snacks for Malnourished Generation. Int. J. Curr. Microbiol. App. Sci. v. 7, n. 01, p. 1293-1307, 2010. DOI: https:// doi.org/10.20546/ijcmas.2018.701.158

PEKSA, A.; KITA, A.; CARBONELL-BARRACHINA, A. A. MIEDZIANKA, J., KOLNIAK-OSTEK, J., TAJNER-CZOPEK, A. Sensory attributes and physicochemical features of corn snacks as affected by different flour types and extrusion conditions. LWT-Food Science and Technology, 72, 26-36, 2016. DOI: 10.1016/j.Iwt.2016.04.034.

PÉREZ-JIMÉNEZ, J; ARRANZ, S; TABERNERO, M. Updated methodology to determine antioxidant capacity in plant foods, oils and beverages: Extraction, measurement and expression of results. Food Research International, v. 41, n. 3, p. 274-285, 2008. DOI: 10.1016/j.foodres.2007.12.004

PRASAD, K.; SINGH, Y.; ANIL, A. Effects of grinding methods on the characteristics of Pusa 1121 rice flour. Journal of Tropical Agriculture and Food Science, v. 40, n. 2, p. 193-201, 2012.

ROCKENBACH, I. I.; GONZAGA, L. V.; RIZELIO, V. M.; GONÇALVES, A. E.; GENOVESE, M. I.; FETT, R.. Phenolic compounds and antioxidant activity of seed and skin extracts of red grape (Vitisvinifera and Vitislabrusca) pomace from Brazilian winemaking. Food Research International. v.44, p. 897-901, 2011. DOI: 10.1016/j.foodres.2011.01.049 
ROMERO P.; FERNÁNDEZ J. I.; BOTÍA P. Interannual climatic variability effects on yield, berry and wine quality indices in long-term deficit irrigated grapevines, determined by multivariate analysis. Inter. J. Wine Res. 8, 3-17, 2016. DOI: 10.2147/IJWR.S107312.

SANDRIN, R.; CAON, T.; ZIBETTI, A. W.; DE FRANCISCO, A. Effect of extrusion temperature and screw speed on properties of oat and rice flour extrudates. Journal of the Science of Food and Agriculture,v. 98, n. 9, p. 3427-3436, 2017. DOI 10.1002/jsfa.8855.

SÁYAGO-AYERDI S. G.; BRENES A.; GOÒI I. Effect of grape antioxidant dietary fiber on the lipid oxidation of raw and cooked chicken hamburgers. LWT-Food Sci. Technol., v 42 p.971-976, 2009. DOI: 10.1016/j.Iwt.2008.12.006

SELANI, M. M.; SHIRADO, G.A.N.; MARGIOTTA, G.B.; SALDAÑA, ERICK; SPADA, F. P.; PIEDADE, S.M.S.; CONTRERAS-CASTILLO, C. J.; CANNIATTI-BRAZACA, S. G. Effects of pineapple by product and canola oil as fat replacers on physicochemical and sensory qualities of low-fat beef burger. Meat Science, Barking, v. 112, n. 1, p. 69-76, 2016. DOI: 10.1016/j.meatsci.2015.10.020

SHI, A. M.; LI, D.; WANG, L. J.; LI, B. Z.; ADHIKARI, B. Preparation of starch-based nanoparticles through high-pressure homogenization and miniemulsion cross-linking: Influence of various process parameters on particle size and stability. Carbohyd Polym., v. 83, p. 1604-1610, 2011. DOI: 10.1016/j.carbpol.2010.10.011

SRICHUWONG, S.; SUNARTI, T. C.; MISHIMA, T.; ISONO, N.; HISAMATSU, M. Starches from different botanical sources II: Contribution of starch structure to swelling and pasting properties. Carbohydrate Polymers, v. 62, n. 1, p. 25-34, 2005. DOI: 10.1016/j.carbpol.2005.03.004

SWAPNIL S. PATIL; MARGARET A BRENNAN; SUE L. MASON;CHARLES S. BRENNAN. The Potential of Combining Cereals and Legumes in the Manufacture of Extruded Products for a Healthy Lifestyle. EC Nutrition, v. 5, n. 2, p. 1120-1127, 2016.

THAIPONG, K.; BOONPRAKOB, U.; CROSBY, K.; CISNEROS-ZEVALLOS, L.; BYRNE, H.D. Comparison of ABTS, DPPH, FRAP and ORAC assays for estimating antioxidant activity from guava fruit extracts. Journal of Food Composition and Analysis, v. 19, p. 669-675, 2006. DOI: 10.1016/j.jfca.2006.01.003.

TOLEDO V.C.S; CARVALHO C.W.P; VARGAS-SOLÓRZANO, J.W.; ASCHERI J.L.R.; COMETTANT-

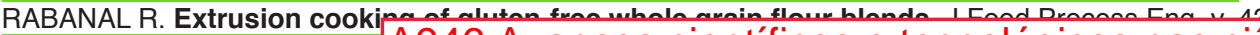
n. 2, 2019. e13303. DOI: 10.11 A946 Avanços científicos e tecnológicos nas ciências agrárias 4

(USP) Universidade de São Pa [recurso eletrônico] / Organizador Júlio César Ribeiro. e Nutrição Experimental/BRAS 5.0 .

- Ponta Grossa, PR: Atena, 2020.
Formato: PDF
Requisitos de sistema: Adobe Acrobat Reader.
Modo de acesso: World Wide Web.
Inclui bibliografia
ISBN 978-65-5706-433-7
DOI 10.22533/at.ed.337202809
1. Agricultura. 2. Ciências ambientais. 3. Pesquisa
agrária - Brasil. I. Ribeiro, Júlio César.




\section{CAPÍTULO 15 \\ PRODUÇ̃̃O E ESTABILIDADE DO CREME DE QUEIJO COALHO COM EXTRATO DE MANJERICÃO (COMO ANTIOXIDANTE NATURAL)}

Data de aceite: 21/09/2020

Data de submissão: 04/06/2020

\section{Alan Rodrigo Santos Teles}

Universidade Federal de Sergipe

São Cristóvão - SE

http://lattes.cnpq.br/1099345984127536

Jucenir dos Santos

Universidade Federal de Sergipe

São Cristóvão - SE

http://lattes.cnpq.br/5496646003413287

Gabriel Francisco Silva

Universidade Federal de Sergipe

São Cristóvão - SE

http://lattes.cnpq.br/0673627615524075

Alessandra Almeida Castro Pagani

Universidade Federal de Sergipe

São Cristóvão - SE

http://lattes.cnpq.br/3377861683609580

RESUMO: O queijo coalho é produzido geralmente por pequenos laticínios, sendo que estes enfrentam grandes problemas devido à necessidade de elaborar novos produtos diferenciados. Uma das formas de aumentar a competitividade das indústrias desse ramo é por meio do valor agregado dos produtos lácteos, como o queijo coalho. Assim sendo, o presente trabalho teve como objetivo elaborar o creme de queijo de coalho e avaliar o efeito da adição do extrato de manjericão como antioxidante natural durante um período de 30 dias de armazenamento.
Foram preparadas três formulações de creme de queijo coalho com e sem a adição do extrato de manjericão nas proporções de 500 e $1000 \mathrm{mg} \cdot \mathrm{kg}^{-1}$. As amostras foram armazenas a $5^{\circ} \mathrm{C}$ e submetidas as análises de $\mathrm{pH}$, acidez titulável e índice de peróxidos para verificação da estabilidade destes durante 30 dias. $\mathrm{O} \mathrm{pH}$, acidez titulável e índice de peróxidos para os cremes de queijo coalho sem a adição de extrato de manjericão e com do extrato de manjericão 500 e 1000 mg.kg-1 foram de $(4,75 \pm 0,08 ; 4,77$ $\pm 0,08 ; 4,74 \pm 0,09),(0,270 \pm 0,008 ; 0,278 \pm 0,010$; $0,276 \pm 0,013) \%$ e $(0,50 \pm 0,05 ; 0,52 \pm 0,07 ; 0,50 \pm$ $0,09)$ meq. $\mathrm{kg}^{-1}$ respectivamente. Após 30 dias de armazenamento os valores de $\mathrm{pH}$, acidez titulável e índice de peróxidos para os cremes de queijo coalho sem a adição de extrato de manjericão e com do extrato de manjericão 500 e 1000 mg. kg ${ }^{-1}$ foram de $(4,40 \pm 0,10 ; 4,58 \pm 0,10 ; 4,64 \pm 0,12)$, $(0,318 \pm 0,007 ; 0,288 \pm 0,01 ; 0,280 \pm 0,008) \%$ e $(4,50 \pm 0,50 ; 2,80 \pm 0,50 ; 1,50 \pm 0,20)$ meq. kg $^{-1}$ para estes parâmetros respectivamente. A adição do extrato de manjericão possibilitou o aumento da estabilidade do creme de queijo coalho, sendo que na proporção de $1000 \mathrm{mg} / \mathrm{kg}$ provocou um aumento maior na estabilidade do creme desse queijo.

PALAVRAS-CHAVE: Lácteos, Ocimum basillicum L., aditivos.

\section{PRODUCTION AND STABILITY OF THE CURD CHEESE CREAM WITH BASIL EXTRACT (AS NATURAL ANTIOXIDANT)}

ABSTRACT: Coalho cheese is normally produced by small dairy products, which face 